\title{
AERIAL PLATFORM RELIABILITY FOR FLOOD MONITORING UNDER VARIOUS WEATHER CONDITIONS: A REVIEW
}

\author{
Shazrizil Zakaria ${ }^{1}$, Muhammad Razif Mahadi ${ }^{1}$, Ahmad Fikri Abdullah ${ }^{1}$, Khalina Abdan ${ }^{1}$ \\ ${ }^{1}$ Department of Biological and Agricultural Engineering, Faculty of Engineering, Universiti Putra Malaysia, 43400 Serdang, \\ Selangor, Malaysia - shazrizil@yahoo.com.my, (razifman, ahmadfikri, khalina)@upm.edu.my
}

Geo-Information for Disaster Management 2018

KEY WORDS: Aerial Platform, Flood Monitoring, Various Weather Condition Operation

\begin{abstract}
:
Flood is an annual disaster in Malaysia, especially in the east coast region. Recently, other regions in Malaysia have also experience devastating flood. A flood aerial monitoring is one of the approaches that involved in the flood disaster management. Compared to space borne remote sensing, aerial platforms are much reliable to obtain higher spatial resolution and real time data. Due to cloud coverage and revisit limitations, space borne remote sensing approach is a less desirable option for flood monitoring. In this paper, a review of existing aerial platforms that perform remote sensing task under various weather conditions, specifically for flood monitoring is presented. There are four types of aerial platforms being reviewed, which are rotary wings, fixed wings, blimps and helikites. The main criteria of the review are the payload capacity, endurance (flight time), altitudes, tolerable wind speed, cost, vertical take-off and landing ability, and the ability to perform under various weather conditions, such as heavy precipitation and winds. From this review, the applications of aerial platform in recent studies never mentioned the capability of aerial platform used in such weather conditions. From all types of aerial platform discussed, helikite seems to be the most suitable to fly in extreme weather. The only drawback is that helikite has mobility issue since it is tethered to the ground. The application of helikite is useful for a small area coverage of flood monitoring. The authors will continue the study to evaluate the reliability of helikite in performing such task in the future.
\end{abstract}

\section{INTRODUCTION}

\subsection{General}

Flood is one of the most prevalent natural disasters, severely distressing mankind and the nature. When the water, ascending beyond its standard level and enveloping the land encompassing it, flooding would make any society, regardless how developed, to become vulnerable (Hamin et al., 2013). It has been assessed that at least 3.5 million people in Malaysia, live in flood plains and are exposed to varying likelihood of flood occurrence (Mustaffa et al., 2014). The rapid urbanization and expansion of land use development, changes in the hydrological cycle, poor storm water management system combined with overwhelming monsoon precipitation, abnormal rain storm's convection and other local features have generated series of flooding in Malaysia (Mohd et al., 2016). Flood will not only impacts human lives, but the damage expands to a lot more such as utilities, infrastructures and road networks, which are often considered to be the backbone of cities (Pregnolato et al., 2017).

Recently, remote sensing has been perceived as a practical instrument to produce near real time inundation maps in according to many researches (Feng et al., 2015). Contrary to the in situ technique, remote sensing can produce concise and continuous flood map coverage occasions, which assists flood monitoring and loss evaluation (Gstaiger et al., 2012). This is due to that the traditional technique of acquiring high resolution data is much more expensive and impossible to sustain yearly long term flood monitoring (Clark, 2017).

However, imageries of satellite remote sensing in the inundated region are seldom available due to revisit limitations. Secondly, the usual used data are incapable to acquire the sophisticated urban landscapes' details due to a relatively lower spatial resolution. Contrasted with orbital surveillance, aerial remote sensing is unaffected to massively cloud covers and revisit limitations, which demonstrates itself as a reliable tool for flood monitoring (Colomina \& Molina, 2014). This review study aims to explore the reliability of unmanned aerial platforms whether they can perform in various weather conditions for collection of data for a real time flood monitoring.

\subsection{Flood History in Malaysia}

Flooding is an event of an abnormal high flow of water over land or coastal area. Flooding is amongst the most catastrophic natural hazards that cause harm to lives and damaging property annually (Kia et al., 2012). Floods have different categories with various behavioural characteristics. The different types of flooding are: flash floods, river floods, urban flooding, and coastal floods (Kourgialas \& Karatzas, 2017). Just like most other tropical countries, Malaysia suffers it aftermath of a flooding occurrence. Although the rainy seasons were once accused for the yearly flood occurrence, today, Malaysia sustains the torment of rapid urbanization and its unpredicted consequences when inordinate storm water incapacitated neighbourhoods and cause broad casualties and damages (Elias et al., 2013). The rapid urbanization of the urban and rural areas has led to mankind centred within the areas that are vulnerable to flood hazards, due to overwhelming monsoon or convective precipitation (Muhamad et al., 2015).

The 2006 - 2007 floods in Malaysia have witnessed uncommonly huge amount of precipitation and has resulted in the displacement of the affected community, especially children (Sipon et al.,

* Corresponding author 
2015). In December 2014, a relentless flood event took place in multiple states located around the east coast of Malaysia peninsular. Thousands were forced to evacuate their homes to designated temporary shelters that were located on higher grounds (Othman et al., 2016). The east coast of Malaysia consisted of Pahang, Terengganu, and Kelantan states were considered as the most severely affected states by the occurrence of flood (Aishah et al., 2015). Recently, at least seven people lost their lives and more than 3,500 others were evacuated in Penang following oppressive flash floods caused by an 18-hour storm which began on 4 November 2017. The flash flood event in Penang is reported as one of the worst since prolonged storms hit Malaysia from December 2014 to January 2015 (OCHA, 2017).

The aftermath of flooding damages assessed by the Malaysian authorities hiked to one billion ringgits (\$284 million USD), from which, 100 million ringgits disposed just to repair roads in Kelantan and 132 million ringgits to repair roads in Terengganu (Ruiz Estrada et al., 2017). Some other recorded flooding history are shown in the Table 1 below.

Table 1: Flooding history record of Malaysia

\begin{tabular}{|c|c|c|c|c|}
\hline $\begin{array}{l}\text { Flood } \\
\text { year }\end{array}$ & Place & $\begin{array}{l}\text { Damages } \\
\text { (USD } \\
\text { million at } \\
1996 \\
\text { prices) }\end{array}$ & Deaths & $\begin{array}{c}\text { No. of } \\
\text { Evacuate } \\
\text { d people }\end{array}$ \\
\hline 1967 & $\begin{array}{c}\text { Kelantan } \\
\text { River Basin }\end{array}$ & 72.31 & 38 & 320,000 \\
\hline 1967 & $\begin{array}{c}\text { Perak River } \\
\text { Basin }\end{array}$ & 56.04 & 0 & 280,000 \\
\hline 1967 & $\begin{array}{l}\text { Terrengganu } \\
\text { River Basin }\end{array}$ & 14.57 & 17 & 78,000 \\
\hline 1971 & $\begin{array}{c}\text { Pahang } \\
\text { River Basin }\end{array}$ & 33.77 & 24 & 153,000 \\
\hline 1984 & $\begin{array}{l}\text { Batu Pahat } \\
\text { River Basin } \\
\end{array}$ & 7.37 & 0 & 8,400 \\
\hline 1986 & $\begin{array}{l}\text { Peninsular } \\
\text { Malaysia }\end{array}$ & 11.96 & 0 & 40,698 \\
\hline 1989 & $\begin{array}{c}\text { Kuala } \\
\text { Lumpur }\end{array}$ & 0.03 & 0 & 220 \\
\hline 1993 & Sabah State & 72.57 & 5 & 5,000 \\
\hline 1995 & $\begin{array}{l}\text { Klang } \\
\text { Valley }\end{array}$ & 1.76 & 1 & 8,970 \\
\hline 1996 & $\begin{array}{c}\text { Pos Dipang, } \\
\text { Perak }\end{array}$ & 97.8 & 44 & Hundreds \\
\hline 2001 & $\begin{array}{l}\text { Kelantan, } \\
\text { Pahang, } \\
\text { Terengganu }\end{array}$ & $\begin{array}{l}0.65 \text { in } \\
\text { crop loss } \\
\text { and } \\
\text { property } \\
\text { damages }\end{array}$ & 5 & $>10,000$ \\
\hline 2001 & $\begin{array}{c}\text { Gunung } \\
\text { Pulai, Johor }\end{array}$ & 4 houses & 5 & 4 families \\
\hline 2007 & $\begin{array}{c}\text { Kelantan } \\
\text { State } \\
\end{array}$ & 17.28 & 18 & 110,000 \\
\hline 2008 & Johor State & 65 & 28 & 34,000 \\
\hline 2010 & $\begin{array}{c}\text { Kedah \& } \\
\text { Perlis States }\end{array}$ & 8.48 & 4 & 50,000 \\
\hline
\end{tabular}

Source: (Ruiz Estrada et al., 2017)

Large developments in urban areas of Malaysia have expanded the amount of impervious surfaces, leading to a huge amount of surface runoff. Moreover, inadequate drainage systems have also lead to flash floods, concentrated in urban areas (Bahrum \& Malek, 2016). There are multiple flooding occasions took place within Kajang town in the previous years, especially in 2008 ,
2011 and 2012. Kajang town suffered one of its worst flash floods in October 2008, inundating almost $70 \%$ of the town. The flood depth is ranging from $0.5 \mathrm{~m}$ to $1.5 \mathrm{~m}$ and brought traffics to a stalemate in major sections of the town. Flooding considered to be definite with Langat River and its tributary Jelok River encumbering to burst their banks just after a short period of rain (Salleh \& Sidek, 2016). Despite having comprehensive structural flood mitigations, Kuala Lumpur, which is situated in the upper Klang River Basin, is still frequently strucked by overwhelming flash floods. The current flood early warning system for the Klang River Basin is operated on the basis of river water levels forecasted from the output of an integrated precipitation or rainfall runoff and flood routing model, which receives inputs from a telemetric rainfall network. However, due to the short response time feasible for the urban catchments during the flash floods, the existing forecasts are not adequate for early warning and rescue operations (Wardah et al., 2008).

\subsection{Flood Disaster Management}

Flood disaster management is a multidimensional approach, and it consist of multiple disciplines such as hydrology, water resource management, statistics, economics, population studies, public policy and emergency response planning. Flood disaster management involves the enhancement of disaster recovery plans to reduce losses and to increase resilience. It can be executed through structural approaches and non-structural approaches (Mohit \& Sellu, 2013). Flood forecasting and monitoring approaches are one of the non-structural approaches. Although it is possible to forecast rainfall or to estimate storm path precisely from satellite images, the requirement to have real-time monitored data such as flow, precipitation level, or water level is crucial to make a reasonable decision on the actions necessary prior to the flooding occurrence (Sunkpho \& Ootamakorn, 2011).

\subsection{Flood Monitoring and Forecasting}

Flood inundation extent, depth, and duration are essential elements influencing flood hazard assessment. The use of digital elevation models (DEM) data with a low spatial resolution usually results in distorted geographical details, where course terrain appears level and smooth, and topographic details such as banks, ditches, and ridges in fields are simplified and unaccounted for. Thus, the foreseeable topographic errors resulted by the low spatial resolution DEMs suggested that flood inundation mapping has proved unfavourable in earlier applications (Shen et al., 2015).

The main purpose of flood extent and hazard mapping is currently to aid in community emergency planning, and is still at an early stage (Zhang et al., 2015). Near-real-time flood maps are also essential to organize and coordinate emergency services' response actions during flooding events (Shen et al., 2015). The issues and approaches in disaster management are presented by Chen et al (2013), where the applications of UAV systems are classified in different application domains that fall into three main groups: monitoring, response and forecast (D. Chen et al., 2013). This classification is done roughly following the disaster management phases, where the forecast group of applications refers to the prevention and preparedness (pre-disaster), the response group refers to the disaster response and recovery (postdisaster), while the monitoring covers the whole disaster cycle, as these applications provide disaster information during all the phases (Erdelj et al., 2017).

Generally, flood mitigation approaches and planning are based on the evaluation of the flood hazard in terms of its location, 
magnitude and distribution. Flood hazard and risk analysis is normally carried out using hydraulic model which can simulate flood inundation extent, water depth and velocity through onedimensional or two-dimensional hydraulic model (Xiao et al., 2017). However, these modelling often carried out from space borne or satellite remote sensing data, which means it is not real time and sometimes the data is affected by cloud covers. To produce a good forecasting or modelling results, an integration between orbital and airborne remote sensors is a good solution to obtain a better spatial and temporal data. Therefore, flood modelling and flood monitoring should be carried out at the same time for a higher accuracy output (Tuna et al., 2012).

Besides, flood modelling requires a lot of data and flood inventories such as lengthy historical rainfall data, water level data, discharges and return period data, and many others. The prime barriers faced while predicting the water surface profile for a water catchments were the relatively insufficient amount of historical data (for both discharge and water level) and the amount limitation of gauging stations placed along the river (Mohammed et al., 2011). This is another reason that flood modelling requires integration of real time monitoring to acquire a more accurate and reliable results.

Flood modelling approach may simulate and produce the flood extent map. However, combined with real time monitoring of flood, a more reliable and accurate results will be obtained. Through aerial image acquisition of flood occurrences and subsequent object based analysis, remarkably dynamic and immeasurable hydraulic phenomena might be able to be quantified at previously unattainable spatial and temporal resolutions. The possibility of this approach to provide reliable information related to the hydraulic conditions present during dynamic, high-energy flash floods has yet to be explored (Perks et al., 2016).

Flood events are somehow formidable to be monitored using solely conventional rainfall stations and river water level stations because they develop at space and time scales that conventional measurement networks of precipitation and river discharges are unable to be sampled effectively (Zoccatelli et al., 2010). Hence, a flood monitoring must also consist of a more creative solution, such as aerial view monitoring to obtain the flood extent map with time-step intervals, to predict loses and damages, and to improve decision-making by emergency responders. To obtain these aerial view monitoring, aerial platform or UAVs can be used to carry small sensors for data acquisitions, which comes to the question of which aerial platforms are the most suitable for a real time flood monitoring under various weather conditions. This paper aims to review the existing aerial platforms and comes to a conclusion of which platforms are best for performing the task of aerial monitoring.

\section{AERIAL PLATFORM APPLICATIONS}

\subsection{Existing Aerial Platforms or UAVs}

The term UAV covers all platform, that is flying airborne with no individual on board, and capable in controlling the vehicle from a certain distance (Eisenbeiss, 2004). There are two major types of aerial platform used for environmental and disaster monitoring purposes which is the rotor copters and the fixed wings (Gomez $\&$ Purdie, 2016). However, there are other kind of airborne platform which is not as popular as the rotor copters and fixed wings, which is blimps and helikites (Klemas, 2013). Their key feature is the ability to be flown by an operator who remains on the ground at a distance from the aircraft itself (Tatham et al., 2017). The classification of aerial platform is also based on their controllability or manoeuvrability characteristics. The difference between rotary wings and fixed wings, to both helikites and blimps is that the operability manoeuvre and mobility (Bernauw, 2016). Helikites and blimps usually requires tethered line stationed statically on a point at the ground compared to fixed wings and rotary wings, which usually remotely controlled and have higher mobility.

\subsection{Aerial Platform Applications}

There are variety of tasks can be performed by using aerial platform and UAV technology, such as aerial mapping, monitoring, and surveillance. The data acquisition of aerial platform includes gliders, kites, airship, balloon, fixed wing and rotary wing UAV, with the variety of modes such as manual, semi-automated or fully autonomous (Tahar \& Ahmad, 2012). The main area of consideration in the setting of criterion for selecting the UAV to use, is the intended purpose, and the times frame that the device is expected to operate without interruptions (Woodget et al., 2017). Besides that, there are other factors that influence the choice of UAV which is the type of the project, the specifications of the UAV, and their suitability to perform the intended task (McMindes, 2005). Various unmanned aerial vehicle has variety of properties that work together to enhance their performance such as payload capacity, endurance (flight time), tolerable wind speed, vertical take-off and landing ability, range of flight control, maximum altitudes, cost and others (Adams et al., 2012).

Both rotor copters and fixed wings have unique advantages and limitations, which make them more or less usable under different weather conditions. Fixed wing UAV has a simple structure compared to the rotor copter. However, fixed wing UAV has an aerodynamic that is more efficient hence advantageous in longer flight duration (Barnhart, 2012). Nonetheless, fixed wing UAV has higher speed of flights as compared to the rotor copters. The higher speed ability of a fixed wing UAV is disadvantageous that loitering aspect of the monitoring project may in some case require high manoeuvrability, which allows for observations in complex landscapes (Klemas, 2015). Therefore, fixed wings are not preferred in such observations since they tend to be restricted to straight line monitoring. Sometimes the preference of rotary wings UAV is based on their lower cost as compared to fixed wings.

Balloon-based aerial platform is one the most efficient devices for collecting data regardless of various weather conditions because they can also mount device that has sensors that use microwave radiations and lasers that can penetrate clouds (Brooks et al., 2013). The application of tethered balloons in remote sensing technology dates originated from the birth of aerial remote sensing itself, when Gaspard Felix Tournachon in 1858 manually acquired aerial photograph near Paris while on board a tethered hot air balloon (X. Chen \& Vierling, 2006). Researchers have begun to put UAVs to a variety of tasks, such as environmental and disaster monitoring. The aerial platforms are able to carry various instrument or device, such as radar (or lidar, the laser-based version) and infrared sensors. Some just simply carry small format digital cameras. Mostly conventional manned aircraft cost several millions of dollars and requires trained pilot to operate one. But for UAV, it is much cheaper and lower the risk of casualties if the flight goes wrongly (Castelvecchi, 2010). For conventional aerial monitoring, it is required to procure an airplane. A manned aircraft or helicopter requires fuel, well-trained pilot and an airstrip or base, which 
could be situated further away from the working site. This results in making the fuel costs even higher, thus, the total operational costs of the conventional airborne monitoring using manned crafts are much more expensive, if compared to UAV platforms (Tamás et al., 2015).

\subsection{UAVs Categories}

Generally, UAVs are piloted aircraft or systems which is controlled remotely within certain range. They can be categorized from basic hand-operated short-range systems to long endurance, high altitude systems that need an airbase. UAVs have domestic, commercial and industrial uses. They are also known as unmanned aerial systems (UAS) or remotely piloted aircraft (RPA) (Brooke-Holland, 2013). UAVs capabilities were studied, compared and evaluated using image processing. The results show that UAVs are capable for surveying and imaging applications (Cano et al., 2017). The category of UAV is shown below in the Table 2 below.

Table 2: Unmanned aerial vehicles (UAVs) categories

\begin{tabular}{|c|c|c|c|c|}
\hline Category & $\begin{array}{c}\text { Mass } \\
(\mathrm{kg})\end{array}$ & $\begin{array}{c}\text { Range } \\
(\mathbf{k m})\end{array}$ & $\begin{array}{c}\text { Altitude } \\
(\mathbf{m})\end{array}$ & $\begin{array}{c}\text { Endurance } \\
\text { (hours) }\end{array}$ \\
\hline Micro & $<5$ & $<10$ & 250 & $<1$ \\
\hline Mini & $\begin{array}{l}25 / \\
30 / \\
150\end{array}$ & $<10$ & $\begin{array}{c}150 / 250 \\
/ 300\end{array}$ & $<2$ \\
\hline Close Range & $\begin{array}{l}25- \\
150\end{array}$ & $10-30$ & 3,000 & $2-4$ \\
\hline Short Range & $\begin{array}{l}50- \\
250\end{array}$ & $30-70$ & 3,000 & $3-6$ \\
\hline Medium Range & $\begin{array}{c}150- \\
500\end{array}$ & $\begin{array}{l}70- \\
200\end{array}$ & 5,000 & $6-10$ \\
\hline $\begin{array}{c}\text { Low Altitude } \\
\text { Long } \\
\text { Endurance } \\
\end{array}$ & $15-25$ & $>500$ & 3,000 & $>24$ \\
\hline $\begin{array}{l}\text { Medium } \\
\text { Altitude Long } \\
\text { Endurance }\end{array}$ & $\begin{array}{c}1,000 \\
\text { to } \\
1,500\end{array}$ & $>500$ & 8,000 & $24-48$ \\
\hline $\begin{array}{l}\text { High Altitude } \\
\text { Long } \\
\text { Endurance } \\
\end{array}$ & $\begin{array}{c}2,500- \\
5,000\end{array}$ & $>2,000$ & 20,000 & $24-48$ \\
\hline Stratospheric & $>2,500$ & $>2,000$ & $>20,000$ & $>48$ \\
\hline
\end{tabular}

\section{REVIEWS ON TYPES OF AERIAL PLATFORM}

From recent studies and literature reviews, the authors will only review four main type of small aerial platforms. They are namely; rotary wings, fixed wings, blimps and helikites.

\subsection{Rotary Wings}

A rotary wing is able to fly and operates in windy conditions up to $50 \mathrm{kmh}^{-1}$. It is capable to perform static flights, which is suitable for monitoring due to the hovering ability. It can mount camera sensors and LIDAR instruments for aerial mapping task as well (Delacourt et al., 2009). Variety kinds of single-rotor UAV have been introduced for photogrammetric data acquisition and topographic modelling (Coppa et al., 2009). Rotary wing UAVs usually demonstrate slower cruising speed and shorter flight durations (up to $50 \mathrm{~min}$ ). Nonetheless, they are able to hover at one fixed position, holding a steady field of view for extensive duration. This provides a moderate spatial and high temporal resolution data. Their capability to circumnavigate in various angle without the need for a runaway greatly ease taking off and landing protocols, making them a perfect device for monitoring (Brouwer et al., 2014). However, flight time of a rotary wing essentially depends on both battery and payload weight. The heavier the payload, the faster the battery drains out (Uysal et al., 2015). Windy conditions also affect the endurance of flight, which also makes the flight time shorter.

In a study by, Watanabe and Kawahara (2016) states that aerial photogrammetry using rotary wings UAVs has reached a level of practical reliability and become a useful platform for spatial data acquisition. Hence, they executed a test and conclude that a rotary wing UAV photogrammetry can acquire river topographical data in a short time and managed to generate a high-resolution digital model of complex river environment with acceptable accuracy (Watanabe \& Kawahara, 2016). A system that combining laser scanner and digital camera with global positioning systems integrated with inertial navigation sensors data was introduced by Nagai et al (2004) to construct digital surface models (DSM). This system uses a Subaru helicopter with $100 \mathrm{~kg}$ of payload and $4.8 \mathrm{~m}$ of diameter for the main rotor, with $3 \mathrm{~km}$ of flight range and 2,000 m of maximum altitude (Nagai et al., 2004). In a study by Sik et al. (2004), a mini-UAV helicopter is demonstrated as an alternative to capture the photographic images of ancient towers and temple sites. The helicopter will be substitute by high camera tripods and ladder trucks, which led to cost inefficiency time consuming. Hirobo \& Eagle 90 used in the study possessed a diameter of main rotor of $1.8 \mathrm{~m}$ and capable to load up a payload until $8.5 \mathrm{~kg}$ (Sik et al., 2004). Casado et al. (2015) identified a hydro morphological features from high resolution RGB aerial imagery by introducing a UAV based framework which using a method based on ANNs. The establishment of the framework was conducted along the river Dee in Wales, United Kingdom. The acquisition of $2.5 \mathrm{~cm}$ resolution image was done by Falcon 8 octocopter. The accuracy of the framework is quite reliable and performing particularly well to obtain aerial image which is shown in the result (Casado et al., 2015).

Mancini et al. (2012) utilized a Structure from Motion (SfM) method to low-altitude aerial imageries gather by rotary wing UAV beneficial from the existence range of terrestrial and aerial techniques. To process the image collected by the rotary UAV system, the structure from Motion appear likely to be a compelling equipment to performing this task. The digital surface models propose conceivable practices in the fields of natural hazards, disaster response and high-resolution terrain analysis as result of accomplishment of the high degree of autonomous framework and $20 \mathrm{~cm}$ level of unconditional vertical accuracy (Mancini et al., 2013). Dubbini et al (2016) presents a creation of a Digital Surface Mode from a low cost, user-friendly, automated hexacopter rotary wings. They focused on the comparison between the Digital Surface Model created using an UAV with a Structure-from-Motion approach, and the digital terrain model already built through a kinematic Global Navigation Satellite System Survey (GNSS). The validation results provided a final vertical accuracy of about $10 \mathrm{~cm}$, which implies that rotary wings are reliable in such aerial mapping task (Dubbini et al., 2016).

Generally, the main advantages of the rotary wings are the VTOL ability, ease of use, having features like autonomous flight and GPS tracking, low cost, and has a good range of flight control up to $1,000 \mathrm{~m}$. However, the main drawbacks of using rotary wings are that it can 't be operated in an extreme wind conditions, heavy precipitations and they have very low endurance (Anweiler \& Piwowarski, 2017). Even though they are good for aerial mapping and surveillance in environmental and disaster research, the low endurance and low robustness makes them unsuitable for a lengthy aerial monitoring in various weather conditions. The examples of rotary wings UAV are shown in the Table 3 below. 
Table 3: Examples of rotary wing UAV

\begin{tabular}{|c|c|c|c|c|}
\hline Model & $\begin{array}{c}\text { Fazer R } \\
\text { G2 }\end{array}$ & $\begin{array}{c}\text { DJI } \\
\text { Inspire } 2\end{array}$ & $\begin{array}{c}\text { DJI } \\
\text { Matrice } \\
200\end{array}$ & $\begin{array}{c}\text { DJI } \\
\text { Matrice } \\
600\end{array}$ \\
\hline $\begin{array}{ll}\text { No. } & \text { of } \\
\text { Motors }\end{array}$ & 1 (Single) & 4 (Quad) & 4 (Quad) & 6 (Hexa) \\
\hline Wingspan & $3.15 \mathrm{~m}$ & $0.63 \mathrm{~m}$ & $0.887 \mathrm{~m}$ & $1.668 \mathrm{~m}$ \\
\hline $\begin{array}{l}\text { Overall } \\
\text { Length }\end{array}$ & $3.66 \mathrm{~m}$ & $0.63 \mathrm{~m}$ & $0.880 \mathrm{~m}$ & $1.518 \mathrm{~m}$ \\
\hline $\begin{array}{l}\text { Cruise } \\
\text { Speed }\end{array}$ & $\begin{array}{l}70-80 \\
\mathrm{kmh}^{-1}\end{array}$ & $\begin{array}{l}70-80 \\
\mathrm{kmh}^{-1}\end{array}$ & $\begin{array}{l}70-80 \\
\mathrm{kmh}^{-1}\end{array}$ & $\begin{array}{c}50-60 \\
\mathrm{kmh}^{-1}\end{array}$ \\
\hline Endurance & $\begin{array}{l}60 \text { min } \\
\text { (fuel) }\end{array}$ & $\begin{array}{c}27 \text { min } \\
\text { (battery) }\end{array}$ & $\begin{array}{c}24 \text { min } \\
\text { (battery) }\end{array}$ & $\begin{array}{c}18 \text { min } \\
\text { (battery) }\end{array}$ \\
\hline $\begin{array}{l}\text { Max } \\
\text { Altitude }\end{array}$ & $2,800 \mathrm{~m}$ & $4,500 \mathrm{~m}$ & $3,000 \mathrm{~m}$ & $2,500 \mathrm{~m}$ \\
\hline Payload & $35 \mathrm{~kg}$ & $0.7 \mathrm{~kg}$ & $1.6 \mathrm{~kg}$ & $5.0 \mathrm{~kg}$ \\
\hline $\begin{array}{l}\text { Wind } \\
\text { Tolerable }\end{array}$ & $20 \mathrm{~ms}^{-1}$ & $10 \mathrm{~ms}^{-1}$ & $12 \mathrm{~ms}^{-1}$ & $8 \mathrm{~ms}^{-1}$ \\
\hline Launch & Vertical & Vertical & Vertical & Vertical \\
\hline Landing & Vertical & Vertical & Vertical & Vertical \\
\hline $\begin{array}{l}\text { Range of } \\
\text { Flight }\end{array}$ & $30,000 \mathrm{~m}$ & $7,000 \mathrm{~m}$ & $7,000 \mathrm{~m}$ & $5,000 \mathrm{~m}$ \\
\hline Cost & $\$ 120,450$ & $\$ 2,999$ & $\$ 9,000$ & $\$ 5,500$ \\
\hline
\end{tabular}

\subsection{Fixed Wings}

Fixed wing UAVs resemble a miniature airplane. Their presence is over two decades and able to fly for long durations and capable to accelerate the speed up to $80 \mathrm{~km}$ per hour. The consolidation of high speed and long endurance allows fixed wing for a task of photogrammetric mapping of larger areas at high spatial resolution (Brouwer et al., 2014). Fixed wing UAVs have flown over cities and wetlands to evaluate damages after earthquakes, hurricanes, and floods. For example, a predator drone can successfully provide infrared imagery that allowed officials and authorities to execute reasonable decisions in a disaster event (Conniff \& McClaran, 2011). The high-resolution fixed wing UAV imagery is proposed by Feng et al. (2015) for urban flood mapping. The fixed wing is an excellent platform for urban flood monitoring proven by a study, and ensure an accurate extraction results under dense urban landscapes for a flood event (Feng et al., 2015).

Nowadays, common fixed wings applications such as surveillance, search, or rescue applications, and these applications need an accurate tracking of inertial trajectories capabilities. However, fixed wing platforms are sensitive to wind that influents the vehicle inertial track. Hence, the trajectory tracking ability of the platform will be jeopardized, in case that the embedded control system does not appointed as a wind disturbances (Brezoescu et al., 2015). Besides, since the landing speed of fixed wing UAV is faster than that of rotary wing UAV, it is essential to consider a lot of space for its own runaways. Unlike rotary wings, fixed wings requires landing strips and a trained pilot to operates the platform. Even with autonomous flight features, fixed wings still requires experts in landing and take-off since it don't have the vertical take-off and landing (VTOL) ability (Fan et al., 2017). Fixed wing platforms only take the advantage of high lift-to-drag ratio, fuel-efficient flying, and high-speed flying, making it a good consideration in aerial mapping. However, long runway and trained pilots are compulsory for take-off and landing, making it a less desirable option compared to rotary wings (Hong et al., 2013). The examples of fixed wings UAV are shown in the Table 4 below.
Table 4: Examples of fixed wing UAV

\begin{tabular}{|l|c|c|c|c|}
\hline Model & $\mathrm{F}-3$ & $\begin{array}{c}\text { Albird } \\
\text { KC3000 }\end{array}$ & F-5 & Chilong \\
\hline Wingspan & $1.7 \mathrm{~m}$ & $3.1 \mathrm{~m}$ & $4.6 \mathrm{~m}$ & $3.1 \mathrm{~m}$ \\
\hline $\begin{array}{l}\text { Overall } \\
\text { Length }\end{array}$ & $0.9 \mathrm{~m}$ & $1.9 \mathrm{~m}$ & $2.8 \mathrm{~m}$ & $2.1 \mathrm{~m}$ \\
\hline $\begin{array}{l}\text { Cruise } \\
\text { Speed }\end{array}$ & $\begin{array}{c}70-90 \\
\mathrm{kmh}^{-1}\end{array}$ & $110 \mathrm{kmh}^{-1}$ & $90 \mathrm{kmh}^{-1}$ & $90 \mathrm{kmh}^{-1}$ \\
\hline Endurance & $\begin{array}{c}90 \mathrm{~min} \\
\text { (battery) }\end{array}$ & $\begin{array}{c}8-10 \mathrm{hr} \\
\text { (fuel) }\end{array}$ & $6 \mathrm{hr}($ fuel) & $4 \mathrm{hr}$ (fuel) \\
\hline $\begin{array}{l}\text { Max } \\
\text { Altitude }\end{array}$ & $3,000 \mathrm{~m}$ & $4,000 \mathrm{~m}$ & $5,000 \mathrm{~m}$ & $3,000 \mathrm{~m}$ \\
\hline Payload & $1.5 \mathrm{~kg}$ & $2.0 \mathrm{~kg}$ & $5.0 \mathrm{~kg}$ & $5.0 \mathrm{~kg}$ \\
\hline $\begin{array}{l}\text { Wind } \\
\text { Tolerable }\end{array}$ & $10 \mathrm{~ms}{ }^{-1}$ & $12 \mathrm{~ms}^{-1}$ & $14 \mathrm{~ms}^{-1}$ & $12 \mathrm{~ms}^{-1}$ \\
\hline Launch & Catapult & Runaway & Runaway & Runaway \\
\hline $\begin{array}{l}\text { Landing } \\
\text { Belly / }\end{array}$ & Runaway & Runaway & Runaway \\
\hline $\begin{array}{l}\text { Range } \\
\text { Flight }\end{array}$ & $3,000 \mathrm{~m}$ & $60,000 \mathrm{~m}$ & $30,000 \mathrm{~m}$ & $30,000 \mathrm{~m}$ \\
\hline Cost & $\$ 35,000$ & $\$ 47,000$ & $\$ 70,000$ & $\$ 60,000$ \\
\hline
\end{tabular}

\subsection{Blimps}

Blimps are also known as non-rigid airships. They are helium filled (gas with lower densities than air) making them float. Blimps carry their propulsion motor in their gondola to move. These propulsion motors were placed in separate nacelles. To allow asymmetric thrust to be applied for manoeuvring, these propulsion motors were mounted towards the sides of the envelope, away from the centre line gondola (Abdul Kadir et al., 2012). They can take off and land vertically without runways (AlJarrah et al., 2013). Blimps come at various sizes, from small for indoors applications, to a bigger one for outdoors applications. Blimps have lower resistance to wind. Due to the flight speed of the blimp which is slower and the blimp is always floating with helium, the blimp's flight does not require any special skill. In this case, blimps become far more user friendly. The payload capacity of a standard blimp is quite small depending on the size (Nitta et al., 2017).

Blimps have been used in several applications of environmental remote sensing concerned with collecting and interpreting information about land, oceans and the atmosphere. Remote sensing using blimps has been applied successfully towards the prediction of weather, as well as in the tracking go of hurricanes, observation of coastal dynamics, and detection of pollutants, as well as mapping of coastal land cover that include forests, agriculture, tidal wetlands, and urban areas (Milstein, 2011). In addition to their application in atmospheric and meteorological surveillance, balloons and blimps are widely applied as aerial platforms to monitor vegetation and crops, rock, soils and geomorphology, hydraulics and hydrographic networks, and to acquire imagery for various other tasks (G. J. J. Verhoeven, 2009). There are two category of blimps, which are free roam and tethered blimps. Lacroix et al (2002) uses $25 \mathrm{~m}^{3}$ tethered blimp to build a fine resolution digital terrain maps, on the basis of a set of low altitude aerial stereovision images. The results show that a blimp can conduct aerial image acquisitions satisfactorily. However, some localization and flight motion problems might occur. Variables such as high wind speed might interfere with the data acquisitions, since the blimps does not perform well in high wind conditions (Lacroix, Jung, \& Mallet, 2002). The examples of blimps are shown in the Table 5 below. 
Table 5: Examples of blimp

\begin{tabular}{|l|c|c|c|c|}
\hline Model & $\begin{array}{c}6 \mathrm{~m} \mathrm{RC} \\
\text { Blimp }\end{array}$ & $\begin{array}{c}7 \mathrm{~m} \mathrm{RC} \\
\text { Blimp }\end{array}$ & $\begin{array}{c}10 \mathrm{~m} \mathrm{RC} \\
\text { Blimp }\end{array}$ & $\begin{array}{c}12 \mathrm{~m} \mathrm{RC} \\
\text { Blimp }\end{array}$ \\
\hline Wingspan & $1.7 \mathrm{~m}$ & $2.0 \mathrm{~m}$ & $2.2 \mathrm{~m}$ & $2.1 \mathrm{~m}$ \\
\hline $\begin{array}{l}\text { Overall } \\
\text { Length }\end{array}$ & $6.0 \mathrm{~m}$ & $7.0 \mathrm{~m}$ & $10.0 \mathrm{~m}$ & $12.0 \mathrm{~m}$ \\
\hline $\begin{array}{l}\text { Cruise } \\
\text { Speed }\end{array}$ & $50 \mathrm{kmh}^{-1}$ & $50 \mathrm{kmh}^{-1}$ & $50 \mathrm{kmh}^{-1}$ & $60 \mathrm{kmh}^{-1}$ \\
\hline Endurance & $\begin{array}{c}60 \mathrm{~min} \\
\text { (battery) }\end{array}$ & $\begin{array}{c}60 \mathrm{~min} \\
\text { (battery) }\end{array}$ & $\begin{array}{c}60 \mathrm{~min} \\
\text { (battery) }\end{array}$ & $\begin{array}{c}70 \mathrm{~min} \\
\text { (battery) }\end{array}$ \\
\hline $\begin{array}{l}\text { Max } \\
\text { Altitude }\end{array}$ & $100 \mathrm{~m}$ & $150 \mathrm{~m}$ & $300 \mathrm{~m}$ & $400 \mathrm{~m}$ \\
\hline Payload & $2.0 \mathrm{~kg}$ & $2.5 \mathrm{~kg}$ & $5.0 \mathrm{~kg}$ & $6.0 \mathrm{~kg}$ \\
\hline $\begin{array}{l}\text { Wind } \\
\text { Tolerable }\end{array}$ & $5 \mathrm{~ms}^{-1}$ & $5 \mathrm{~ms}^{-1}$ & $7 \mathrm{~ms}^{-1}$ & $10 \mathrm{~ms}^{-1}$ \\
\hline Launch & VTOL & VTOL & VTOL & VTOL \\
\hline Landing & VTOL & VTOL & VTOL & VTOL \\
\hline $\begin{array}{l}\text { Range of } \\
\text { Flight }\end{array}$ & $100 \mathrm{~m}$ & $150 \mathrm{~m}$ & $300 \mathrm{~m}$ & $400 \mathrm{~m}$ \\
\hline Cost & $\$ 7,200$ & $\$ 8,800$ & $\$ 14,500$ & $\$ 35,000$ \\
\hline
\end{tabular}

\subsection{Helikites}

Helikite is a unique design associating two aforementioned constructions. The combination between helium air balloon with kite wing made them lighter than air device merges the attributes of both medium. The balloon filled by helium allowing it to launch in windless weather conditions, while the kite features become essential in the wind presence. First and foremost, the construction is lifted up in the air to altitudes higher than the pure helium lift. The lift ability of helikite becomes more solid with accelerating wind speed. Next, the wings counteract any unstable behaviour that is characteristic of balloons and blimps flown in windy conditions, hence stabilizing the helikite (Verhoeven et al., 2009). Because of its capability to acquire an extremely high temporal resolution imagery (the system ability to record images at a certain time span, for example one day versus one month), a quick response to events and short time span for site-based monitoring is likely to happen with helikite. By combining helium balloon with non-metric digital singe reflex camera and additional surveying methods, a low altitude photogrammetry is produced and this photogrammetry demonstrates an efficient result in mapping small and medium size areas of interest (Mozas-Calvache et al., 2012). Traditionally, the main challenge using these platforms is the irregular geometry of the photographs obtained. Usually, to acquire the photograph with irregular geometry by using these platforms is the utmost challenge. Uncontrolled circumstances (such as wind effect and lack of flight control) generate high imprecision in the setting of camera sensors which cause these block pattern with irregular image.

A study by Vericat et al. (2008) evaluated the field and laboratory method needed to develop georeferenced photo-mosaics which come from aerial images captured by digital camera set on a helium helikite and provide valuation of their reliability. The usage of photo mosaic can speed up routine systems monitoring, for instance mapping dynamic channel morphology or changes in habitat suitability (Vericat et al., 2008). Fonstad et al. (2013) tested the utility of the Structure from Motion photogrammetric approach using a helikite platform, and found it to be accurate and precise, even when compared to aerial Lidar data. The technique is upstanding, and requires less of time for raw data collection and data processing. Current advancement in software tools and application should afford exactly that, providing high quality topographic datasets results (Fonstad et al., 2013). Verhoeven et al. (2012) shown that an association of a lowcost acquisition method and an unsophisticated, computer visionbased processing workflow can yield a highly accurate digital surface model and ortho photograph of a wide and intricate site. After a difficult data acquisition stage with a helikite based platform, a Structure from Motion approach automatically estimated all the necessary camera parameters and aligned the large set of unordered images. Subsequently, a dense multi-view stereo algorithm was applied to generate a digital surface model. As a result, this method largely accounted for all possible kinds of geometrical degradations and was able to process a large, unstructured collection of aerial images into a $3 \mathrm{D}$ representation and ortho photograph of an area. In this way, even the nonspecialist in the field of photogrammetry or geodesy can create highly accurate ortho photographs using currently available and affordable technology (G. Verhoeven et al., 2012). Examples of helikites are shown in the Table 6 below.

Table 6: Examples of helikite

\begin{tabular}{|l|c|c|c|c|}
\hline Model & $\begin{array}{c}6 \mathrm{~m}^{3} \\
\text { Skyhook }\end{array}$ & $\begin{array}{c}7 \mathrm{~m}^{3} \\
\text { Skyhook }\end{array}$ & $\begin{array}{c}9 \mathrm{~m}^{3} \\
\text { Skyhook }\end{array}$ & $\begin{array}{c}11 \mathrm{~m}^{3} \\
\text { Skyhook }\end{array}$ \\
\hline Wingspan & $2.14 \mathrm{~m}$ & $2.44 \mathrm{~m}$ & $2.74 \mathrm{~m}$ & $2.90 \mathrm{~m}$ \\
\hline $\begin{array}{l}\text { Overall } \\
\text { Length }\end{array}$ & $3.35 \mathrm{~m}$ & $3.5 \mathrm{~m}$ & $3.57 \mathrm{~m}$ & $3.66 \mathrm{~m}$ \\
\hline $\begin{array}{l}\text { Cruise } \\
\text { Speed }\end{array}$ & Tethered via dyneema cable from the ground \\
\hline Endurance & \multicolumn{5}{|c|}{ Depends on sensors and gimbal battery only } \\
\hline $\begin{array}{l}\text { Max } \\
\text { Altitude }\end{array}$ & $1,500 \mathrm{~m}$ & $1,600 \mathrm{~m}$ & $1,700 \mathrm{~m}$ & $1,800 \mathrm{~m}$ \\
\hline Payload & $2.7 \mathrm{~kg}$ & $3.2 \mathrm{~kg}$ & $4.0 \mathrm{~kg}^{-1}$ & $5.5 \mathrm{~kg}$ \\
\hline $\begin{array}{l}\text { Wind } \\
\text { Tolerable }\end{array}$ & $17 \mathrm{~ms}^{-1}$ & $17.89 \mathrm{~ms}{ }^{-1}$ & $18.77 \mathrm{~ms}^{-1}$ & $17.89 \mathrm{~ms}{ }^{-1}$ \\
\hline Launch & VTOL & VTOL & VTOL & VTOL \\
\hline Landing & VTOL & VTOL & VTOL & VTOL \\
\hline $\begin{array}{l}\text { Range } \\
\text { Flight of }\end{array}$ & Stationary at one hovering point (due to tethering) \\
\hline Cost & \$2,500 & \$2,555 & \$3,000 & \$3,450 \\
\hline
\end{tabular}

\subsection{UAV Application in Previous Studies}

The Table 7 below shows previous study regarding the various application of aerial platform and remote sensing.

Table 7: Previous study involving UAV applications

\begin{tabular}{|c|c|c|}
\hline $\begin{array}{c}\text { Author, } \\
\text { Year }\end{array}$ & Content of Study & $\begin{array}{c}\text { Platform } \\
\text { Used }\end{array}$ \\
\hline $\begin{array}{l}\text { (Allsopp, } \\
2010 \text { ) }\end{array}$ & $\begin{array}{l}\text { Clarify the capability of a tethered } \\
\text { Helikite as a reliable aerial platform } \\
\text { and list out some of the recent work } \\
\text { done related to the platform. The } \\
\text { author shows the simplicity in } \\
\text { creating a robust, long-range aerial } \\
\text { internet protocol ad-hoc networks } \\
\text { for the military and elaborate the } \\
\text { importance of these networks for the } \\
\text { years to come. }\end{array}$ & Helikite \\
\hline $\begin{array}{l}\text { (Mozas- } \\
\text { Calvache et } \\
\text { al., 2012) }\end{array}$ & $\begin{array}{l}\text { Demonstrates a photogrammetric } \\
\text { survey of archaeological sites using } \\
\text { a small lighter than air aerial } \\
\text { platform. The results demonstrate } \\
\text { the viability of the methodology } \\
\text { proposed even when moderate wind } \\
\text { effects are present. }\end{array}$ & Helikite \\
\hline $\begin{array}{l}\text { (Ajibola \& } \\
\text { Mansor, } \\
\text { 2013) }\end{array}$ & $\begin{array}{l}\text { Use of a fixed wing UAV which } \\
\text { acquire aerial images of a flooded } \\
\text { area to develop topographic map for } \\
\text { flood control measures. }\end{array}$ & Fixed Wing \\
\hline $\begin{array}{l}\text { (Al-Jarrah } \\
\text { et al., 2013) }\end{array}$ & $\begin{array}{l}\text { Demonstrates a fuzzy controller and } \\
\text { a robust embedded visual system to } \\
\text { follow a ground robot target by an }\end{array}$ & Indoor Blimp \\
\hline
\end{tabular}




\begin{tabular}{|c|c|c|}
\hline $\begin{array}{c}\text { Author, } \\
\text { Year }\end{array}$ & Content of Study & $\begin{array}{c}\text { Platform } \\
\text { Used }\end{array}$ \\
\hline & $\begin{array}{l}\text { indoor blimp to complete navigation } \\
\text { performance. }\end{array}$ & \\
\hline $\begin{array}{l}\text { (Gerke et } \\
\text { al., 2013) }\end{array}$ & $\begin{array}{l}\text { Demonstrate on the enhancement of } \\
\text { an autonomous mode blimps for } \\
\text { applications in environmental } \\
\text { monitoring for longer endurance. } \\
\text { This covers direct monitoring from } \\
\text { the air, with cameras, radar, lidar, } \\
\text { gas, temperature, and humidity } \\
\text { sensors. A new application field } \\
\text { presented in the study is the } \\
\text { interaction of ground based sensors } \\
\text { with the blimp. This allows wireless } \\
\text { data gathering even in large-scale or } \\
\text { remote areas. Results show that } \\
\text { blimp endurance can be extended } \\
\text { via extra batteries installation. }\end{array}$ & Blimp \\
\hline $\begin{array}{l}\text { (Brouwer et } \\
\text { al., 2014) }\end{array}$ & $\begin{array}{l}\text { Investigates the potential of rotary } \\
\text { wing UAV to monitor the surf zone. } \\
\text { Rotary wing UAV is a flexible } \\
\text { surveying platforms that can gather } \\
\text { near continuous moderate spatial } \\
\text { resolution and high temporal } \\
\text { resolution imagery from a fixed } \\
\text { position high above the study site. }\end{array}$ & Rotary Wing \\
\hline $\begin{array}{l}\text { (Flynn \& } \\
\text { Chapra, } \\
\text { 2014) }\end{array}$ & $\begin{array}{l}\text { Elaborates a method for remote } \\
\text { sensing of the green algae in rivers } \\
\text { using a rotary wing UAV. Included } \\
\text { are methods for UAV operation, } \\
\text { lens distortion correction, image } \\
\text { geo-referencing, and spectral } \\
\text { analysis. Results indicate that } \\
\text { optical remote sensing using rotary } \\
\text { wing UAV can yield promising data } \\
\text { for completing spatially precise, and } \\
\text { multi-temporal measurements with } \\
\text { low turbidity and good optical } \\
\text { transmission. }\end{array}$ & Rotary Wing \\
\hline $\begin{array}{l}\text { (Kadir \& } \\
\text { Arshad, } \\
\text { 2015) }\end{array}$ & $\begin{array}{l}\text { Presents a cooperative decision } \\
\text { making problem of multi agent } \\
\text { system for ocean observation system } \\
\text { using a team of agents consisting of } \\
\text { three blimps and buoys. The aim is } \\
\text { to obtain cohesion in heading for the } \\
\text { multi blimp to assist aerial mapping } \\
\text { and act as the communication hub } \\
\text { for a series of ODAS buoy. The } \\
\text { results show fast converges of } \\
\text { consensus and the effectiveness } \\
\text { were demonstrated through } \\
\text { numerical simulations. }\end{array}$ & Blimp \\
\hline $\begin{array}{l}\text { (Brezoescu } \\
\text { et al., 2015) }\end{array}$ & $\begin{array}{l}\text { Addresses the directional control } \\
\text { problem of autonomous fixed wing } \\
\text { UAV in order to obtain trajectory } \\
\text { tracking capabilities when flying in } \\
\text { other than calm conditions. }\end{array}$ & Fixed Wing \\
\hline $\begin{array}{l}\text { (Arango \& } \\
\text { Morales, } \\
\text { 2015) }\end{array}$ & $\begin{array}{l}\text { Comparison between multi copter } \\
\text { UAV and Total Station for } \\
\text { estimating stockpile volumes, } \\
\text { concluding that the estimated } \\
\text { volume with UAV data is more } \\
\text { accurate. }\end{array}$ & Rotary Wing \\
\hline $\begin{array}{l}\text { (Casado et } \\
\text { al., 2015) }\end{array}$ & $\begin{array}{l}\text { UAV based framework using } \\
\text { octocopter for the identification of } \\
\text { hydro morphological features from } \\
\text { high resolution RGB aerial imagery } \\
\text { using a novel classification } \\
\text { technique based on ANNs. }\end{array}$ & Rotary Wing \\
\hline $\begin{array}{l}\text { (Feng et al., } \\
2015 \text { ) }\end{array}$ & $\begin{array}{l}\text { Acquiring optical imagery by a } \\
\text { mini-UAV to monitor the serious } \\
\text { urban waterlogging in Yuyao, } \\
\text { China. The results demonstrate that } \\
\text { UAV can provide an ideal platform }\end{array}$ & Fixed Wing \\
\hline
\end{tabular}

\begin{tabular}{|c|c|c|}
\hline $\begin{array}{l}\text { Author, } \\
\text { Year }\end{array}$ & Content of Study & $\begin{array}{c}\text { Platform } \\
\text { Used }\end{array}$ \\
\hline & $\begin{array}{l}\text { for urban flood monitoring and the } \\
\text { proposed method shows great } \\
\text { capability for the accurate extraction } \\
\text { of inundated areas }\end{array}$ & \\
\hline $\begin{array}{l}\text { (Tamás } \\
\text { Fráter et al., } \\
2015 \text { ) }\end{array}$ & $\begin{array}{l}\text { Aerial photos for environmental } \\
\text { monitoring were made in Bakony } \\
\text { Mountains using UAVs equipped } \\
\text { with small HD cameras. A small } \\
\text { lake was photographed. The } \\
\text { application of these platforms for } \\
\text { environmental monitoring is } \\
\text { advantageous, especially in case of } \\
\text { natural reserve areas since those are } \\
\text { very silent and contrary to big } \\
\text { aircrafts and helicopters, UAV do } \\
\text { not disturb the ecology even in } \\
\text { natural reserve areas and the people } \\
\text { living there. }\end{array}$ & $\begin{array}{l}\text { Fixed Wing } \\
\text { Rotary Wing }\end{array}$ \\
\hline $\begin{array}{l}\text { (Polo et al., } \\
2015)\end{array}$ & $\begin{array}{l}\text { Propose an agricultural environment } \\
\text { monitoring server system utilizing a } \\
\text { low-cost Wireless Sensor Network } \\
\text { (WSN). To cover long distances in a } \\
\text { short period of time, the authors } \\
\text { used a fixed wing UAV, which } \\
\text { retrieves the data stored in the } \\
\text { ground nodes. In addition, the UAV } \\
\text { may be used to acquire additional } \\
\text { information and to perform actions. } \\
\text { Its elevated position allows } \\
\text { observation of the field with a } \\
\text { perspective that is useful for } \\
\text { detecting changes affecting crops, } \\
\text { such as pests, diseases, significant } \\
\text { changes in soil moisture, drought or } \\
\text { floods. }\end{array}$ & Fixed Wing \\
\hline $\begin{array}{l}\text { (Clapuyt, } \\
\text { Vanacker, } \\
\text { \& Van Oost, } \\
\text { 2016) }\end{array}$ & $\begin{array}{l}\text { Combination of UAV-based aerial } \\
\text { pictures and Structure-from-Motion } \\
\text { (SfM) algorithm provides an } \\
\text { efficient, low-cost and rapid } \\
\text { framework for remote sensing and } \\
\text { monitoring of dynamic natural } \\
\text { environments. The methodology is } \\
\text { particularly suitable for repeated } \\
\text { topographic surveys in remote or } \\
\text { poorly accessible areas. }\end{array}$ & Rotary Wing \\
\hline $\begin{array}{l}\text { (Dubbini et } \\
\text { al., 2016) }\end{array}$ & $\begin{array}{l}\text { The comparison between the digital } \\
\text { surface model created using a UAV } \\
\text { with a structure-from-motion } \\
\text { approach, and the digital terrain } \\
\text { model already built through a } \\
\text { kinematic Global Navigation } \\
\text { Satellite System survey. The results } \\
\text { of the validation provided a final } \\
\text { vertical accuracy of about } 10 \mathrm{~cm} \text {. }\end{array}$ & Rotary Wing \\
\hline $\begin{array}{l}\text { (Anweiler } \\
\& \\
\text { Piwowarski, } \\
\text { 2017) }\end{array}$ & $\begin{array}{l}\text { Design and manufacture a low cost } \\
\text { and low weight quadcopter platform } \\
\text { prototype for the purpose of the } \\
\text { environmental monitoring and } \\
\text { research. }\end{array}$ & Rotary Wing \\
\hline $\begin{array}{l}\text { (Cano et al., } \\
2017 \text { ) }\end{array}$ & $\begin{array}{l}\text { The study of an image processing } \\
\text { approach to make comparison of } \\
\text { two rotary wing UAV of different } \\
\text { model. The comparative analysis of } \\
\text { the two UAV involves a rectilinear } \\
\text { motion test and a hovering test. } \\
\text { Results demonstrated that both } \\
\text { UAV performed well in both test } \\
\text { and thus demonstrated that the UAV } \\
\text { is capable for many other } \\
\text { applications. }\end{array}$ & Rotary Wing \\
\hline $\begin{array}{l}\text { (Clark, } \\
\text { 2017) }\end{array}$ & $\begin{array}{l}\text { Analysis of comparing between a } \\
\text { quadcopter and fixed wing UAV. } \\
\text { The flexibility and inexpensive }\end{array}$ & $\begin{array}{l}\text { Fixed Wing } \\
\text { Rotary Wing }\end{array}$ \\
\hline
\end{tabular}




\begin{tabular}{|c|c|c|}
\hline 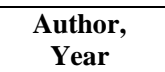 & Content of Study & $\begin{array}{l}\text { Platform } \\
\text { Used }\end{array}$ \\
\hline & $\begin{array}{l}\text { operating cost of UAV allows } \\
\text { repetitive surveys of study sites to } \\
\text { monitor annual coastal changes and } \\
\text { examine the impacts of individual } \\
\text { storms. Result shows that rotary } \\
\text { wing is more accurate. }\end{array}$ & \\
\hline $\begin{array}{l}\text { (Cook, } \\
2017)\end{array}$ & $\begin{array}{l}\text { Deployment of a regular low cost } \\
\text { UAV for the acquisition of a high } \\
\text { resolution topography in the Daan } \\
\text { River gorge in western Taiwan. } \\
\text { Aerial surveys using a rotary wing } \\
\text { UAV were conducted alongside } \\
\text { with terrestrial lidar surveys, to test } \\
\text { the reliability of the UAV survey for } \\
\text { detecting geomorphic changes. The } \\
\text { results suggest that even very simple } \\
\text { UAV can yield data suitable for } \\
\text { measuring geomorphic change on } \\
\text { the scale of a channel reach. }\end{array}$ & Rotary Wing \\
\hline $\begin{array}{l}\text { (Erdelj et } \\
\text { al., 2017) }\end{array}$ & $\begin{array}{l}\text { Focus on the joint role that Wireless } \\
\text { Sensor Network and multi-UAV } \\
\text { systems can play in this context, } \\
\text { and, as first contribution, present a } \\
\text { detailed overview of recent research } \\
\text { efforts for using the two } \\
\text { technologies to improve the } \\
\text { efficiency of disaster management } \\
\text { systems. }\end{array}$ & Rotary Wing \\
\hline $\begin{array}{l}\text { (Nitta et al., } \\
\text { 2017) }\end{array}$ & $\begin{array}{l}\text { Demonstrates a method of aerial } \\
\text { visual inspection for a ceiling } \\
\text { compartment of a gymnasium using } \\
\text { an indoor blimp carrying a simple } \\
\text { affordable Wi-Fi camera. The aim of } \\
\text { the study was to locate the damage } \\
\text { and captures photographic images of } \\
\text { the damaged section of the ceiling. } \\
\text { The inspection conducted was able } \\
\text { to evaluate the damage condition of } \\
\text { the ceiling compartment and the } \\
\text { result was proved to be reliable. }\end{array}$ & Indoor Blimp \\
\hline
\end{tabular}

\section{RESULTS AND DISCUSSIONS}

\subsection{Comparison of Aerial Platform}

From the overview of the literature, the comparison between UAVs are made and shown in the Table 8 below.

Table 8: Comparison between aerial platforms reviewed

\begin{tabular}{|c|c|c|c|c|}
\hline Criteria & $\begin{array}{c}\text { Rotary } \\
\text { Wings }\end{array}$ & $\begin{array}{c}\text { Fixed } \\
\text { Wings }\end{array}$ & Blimps & Helikite \\
\hline $\begin{array}{c}\text { High Payload } \\
\text { Capacity }\end{array}$ & $\sqrt{ }$ & $\sqrt{ }$ & $\sqrt{ }$ & $\sqrt{ }$ \\
\hline $\begin{array}{c}\text { Wide Area } \\
\text { Coverage }\end{array}$ & $\sqrt{ }$ & & \\
\hline $\begin{array}{c}\text { Extreme } \\
\text { Endurance }\end{array}$ & $\sqrt{ }$ & $\sqrt{ }$ & & $\sqrt{ }$ \\
\hline High Altitude & $\sqrt{ }$ & & $\sqrt{ }$ \\
\hline $\begin{array}{c}\text { All Weather } \\
\text { Operation }\end{array}$ & & $\sqrt{ }$ & \\
\hline $\begin{array}{c}\text { Autonomous } \\
\text { Operation }\end{array}$ & $\sqrt{ }$ & & $\sqrt{ }$ & $\sqrt{ }$ \\
\hline Easy Operation & $\sqrt{ }$ & & $\sqrt{ }$ & $\sqrt{ }$ \\
\hline VTOL Ability & $\sqrt{ }$ & & $\sqrt{ }$ & $\sqrt{ }$ \\
\hline $\begin{array}{c}\text { Inexpensive } \\
\text { Cost }\end{array}$ & $\sqrt{ }$ & & & \\
\hline $\begin{array}{c}\text { High wind } \\
\text { tolerance }\end{array}$ & & & & \\
\hline \multicolumn{2}{|c|}{} \\
\hline
\end{tabular}

From the Table 8, all platform can carry high capacity of payload. However, that depends on their size. The bigger the platform is, the heavier the payload they can carry. In terms of area of coverage, fixed wing UAV present the best option. With greater cruising speed and endurance, this features allows them to stay airborne longer and further for a data acquisition mission. Rotary wings have short durations, same goes the blimps, with limited lifespan of batteries. Helikite however, have good endurance since it uses helium as its lifting force and allows is stay afloat longer than the fixed wings UAV. From the finding, most aerial platforms are unable to operate in various weather condition, and have low tolerable wind speed resistance. Helikites, however, has the all-weather operation capability and have better tolerable wind speed, making it a potential aerial platform for a task of aerial remote sensing, such as flood monitoring.

\subsection{Discussions}

Research shows that the fixed wing UAV have a rigid wing with a predetermined air foil that enables the device to fly through the airlift concept. The airlift occurs due to the forward airspeed of the UAV. The fixed wing has a simpler structure than the rotary wings. The simplicity of the fixed wing structure requires less complex repair and maintenance process. The ease of repair and maintenance enable the fixed wing user to have higher operational time at a lower cost than the rotary wing user. Moreover, the simple structure of the fixed wing design provides efficient aerodynamics, thus the long flight duration advantage making it possible to carry out surveillance and monitoring tasks on large area per flight. With extended flight duration, this makes the fixed wings more suitable for an aerial monitoring than the rotary wing devices because they can capture the required georeferenced data over a larger area. However, fixed wings performance is limited by it dependency on a runway or a launcher to facilitates its take-off and landing. The motioned limitation also affects the weight of the payload the fixed wing UAV can carry.

The rotary wing functionality is similar to that of the fixed wing, but it does not require the forward thrust to initiate the flight movement. The flight is initiated by the constant rotation of the rotor blades that creates the air movement over their air foil and generates the lift. The rotary wing UAV has a higher level of mechanical complexity that the fixed-wing UAV. Furthermore, the rotor copter has a lower range of flight with most of them having at most several minutes' flight time, depending on the load capacity. Rotary wings have an advantage as they are able to use a vertical take-off and landing protocols, as well as the ability to have agile manoeuvring and hovering property. This makes the rotor copter the best devices for conducting local inspection tasks as they are able to maintain visual on a specific target for a long time. Mover their take-off independence gives them higher flexibility and efficiency in deploying the payloads. Besides, the vertical take-off and landing procedures have been developed as a solution for a problem faced by the fixed wing UAV given that they need the runaway or launcher for take-off.

Blimps have been used in several applications of environmental remote sensing concerned with collecting and interpreting information about land, oceans and the atmosphere. Remote sensing using blimps has been applied successfully towards the prediction of weather, as well as in the tracking go of hurricanes, observation of coastal dynamics, and detection of pollutants, as well as mapping of coastal land cover that include forests, agriculture, tidal wetlands, and urban areas. Blimps are lowflying long-endurance and slow aircraft, which accommodate a 
monitoring platform necessary for long term monitoring and observation of the intended target location. Blimps have the added advantage of not requiring excess fuel like aircrafts to fly since they are operated using helium gas, which is lighter than air thus enabling them to float by the buoyant force. The shape proves to be the most economical and efficiently used in calm and light and conditions, amongst all the balloon shapes. These include wind conditions that are less than 15 kilometres per hour. Unmanned blimps are advantageous over the manned ones since they cost less to purchase and operate. Blimps are mostly used in small-frontal aerial photography, where there is a choice among many types of blimps for commercial use. Blimps have the desired effect of durability in field conditions. Depending on the size, different blimps have different payload capacities. The stabilization of the blimps in flight is achieved by the use of four rigid tail fins, as well as multiple attachment points positioned along the kill, which help in allowing for the fastening of the camera system and the tether line that weight up to 1.5 kilograms. Many operations and tasks have been deployed from a helium filled blimp whereby the blimp carried a downward looking camera that was designed for the transmission of images wirelessly to an on board terminal, which allowed the displaying of the pictures in real time.

The helikite is characterized by an ease in lift since it can easily carry a payload in windless conditions the functionality of the helikite in windy conditions is based on the stabilization of the balloon by the kite section, which increases its payload capacity. The cost of the helikite is extremely low making it a cost effective platform for flood monitoring and other types of monitoring. One of the greatest advantages of the helikite is the ability to modify it according to the required specifications. Some of the specifications that can be fitted into the design of the helikite include a thermal infrared camera, a digital camera, an inertial measurement unit, GPS equipment and other more sophisticated equipment, which makes the helikite a versatile monitoring system. The helikite is characterized by longevity since it can stay airborne for several weeks at a time. Helikites are highly desirable in monitoring since they provide automatic flight in any weather condition, be it windy, stormy or heavy rains. In addition, the reduction of camera shaking to provide accurate photography is an attribute that sets helikites apart since the helikite platform is very stable. Steady camera is critical in environmental monitoring as stability enhances quality and prevents the loss of expensive digital cameras and other equipment by falling. Besides, there is no need for technical knowledge, which makes everyone capable of flying a helikite within minutes. The safety level of helikites is above that of most UAV. Therefore, safety precautions in the use of helikites are quite minimal. While most drones fly in wind at $14 \mathrm{~ms}^{-1}$, helikites can fly at speeds of up to $18 \mathrm{~ms}^{-1}$ windy conditions.

\section{CONCLUSIONS}

The reviews indicate that most of the studies didn't mention the capability of the aerial platforms used to perform under various weather conditions, such as heavy rainfall and windy condition. It provides a gap to be explored of which instrument or device is capable to do so to acquire real time data under certain amount of period continuously. From this findings, the opportunity to explore the type of aerial platform that can perform under various weather condition does exist and requires attention. With this gap, the authors interested in selecting the best suitable robust and reliable aerial platform for a real time flood monitoring task. From the results, the helikite seems to be suitable for the task of monitoring due to the ability to operate under various weather conditions. Even though it is lack in mobility and may only cover small area coverage, this would give a higher spatial resolution and temporal data in a local area prone to the flood event. The authors seek to test the reliability of helikite platform in the future.

\section{ACKNOWLEDGEMENTS}

Special thanks and appreciation for the Department of Biology and Agricultural Engineering, Faculty of Engineering, Universiti Putra Malaysia, for the data, facilities, and expert opinion,

\section{REFERENCES}

Abdul Kadir, H., Arshad, M. R., \& Husaini, A. B. (2012). Modeling and Control Analysis of URRG Monohull Blimp. Procedia Engineering, 41, 216-223.

Adams, W., Ambrosia, V. G., \& Hinkley, E. A. (2012). Unmanned Aircraft Systems in Remote Sensing and Scientific Research: Classification and Considerations of Use. Remote Sensing, 4(6), 1671-1692.

Aishah, T. S., Wok, S., Maznina, A., Manaf, A., \& Ismail, R. (2015). Exploring the Use of Social Media During the 2014 Flood in Malaysia. Procedia - Social and Behavioral Sciences, 211, 931-937.

Ajibola, I. I., \& Mansor, S. (2013). UAV Based Imaging for Environmental Sustainability - Flash Floods Control Perspective. Proceedings of FIG Working Week, Environment for Sustainability, 1-15.

Al-Jarrah, R., Jellal, R. A., \& Roth, H. (2013). Blimp Based on Embedded Computer Vision and Fuzzy Control for Following Ground Vehicles. IFAC Symposium on Telematics Applications (Vol. 3).

Allsopp, S. (2010). Helikites for High-Altitude Radio-Relay White Paper. England.

Anweiler, S., \& Piwowarski, D. (2017). Multicopter Platform Prototype for Environmental Monitoring. Journal of Cleaner Production, 155, 204-211.

Arango, C., \& Morales, C. A. (2015). Comparison Between Multicopter UAV and Total Station for Estimating Stockpile Volumes. International Archives of the Photogrammetry, Remote Sensing and Spatial Information Sciences, XL(1/W4), 131-135.

Bahrum, N. A., \& Malek, M. A. (2016). Hydrological Analysis on Semi-Urban and Urban Areas in Kajang. International Journal of New Technology and Research (IJNTR), 2(1), 58-66.

Barnhart, R. K. (2012). Introduction to Unmanned Aircraft Systems. (S. B. Hottman, D. Marshall, \& E. Shappee, Eds.). Boca Raton, Florida: Taylor \& Francis.

Bernauw, K. (2016). Drones: The Emerging Era of Unmanned Civil Aviation. Zbornik PFZ, 66(2-3), 223-248.

Brezoescu, A., Lozano, R., \& Castillo, P. (2015). Lyapunov- 
Based Trajectory Tracking Controller for a Fixed Wing Unmanned Aerial Vehicle in the Presence of Wind. International Journal of Adaptive Control and Signal Processing, 29, 372-384.

Brooke-Holland, L. (2013). Unmanned Aerial Vehicles (Drones): An Introduction. Retrieved from http://www.parliament.uk/business/publications/research/briefin g-papers/SN06493/unmanned-aerial-vehicles-drones-anintroduction

Brooks, B. a, Hudnut, K. W., Ericksen, T., Hauser, D., \& Glennie, C. L. (2013). Mobile Laser Scanning Applied to the Earth Sciences. EOS, 94(36), 313-315.

Brouwer, R., Schipper, M. De, Rynne, P., Graham, F., Reniers, J., \& MacMahan, J. (2014). Surfzone Monitoring Using Rotary Wing Unmanned Aerial Vehicles. Journal of Atmospheric and Oceanic Technology, 32, 855-863.

Cano, E., Horton, R., Liljegren, C., \& Bulanon, D. (2017). Comparison of Small Unmanned Aerial Vehicles Performance Using Image Processing. Journal of Imaging, 3, 4-18.

Casado, M. R., Gonzalez, R. B., Kriechbaumer, T., \& Veal, A. (2015). Automated Identification of River Hydromorphological Features Using UAV High Resolution Aerial Imagery. Sensors, 15(11), 27969-27989.

Castelvecchi, D. (2010). Invasion of the Drones: Unmanned Aircraft Take Off in Polar Exploration. Scientific American, 302, $25-27$.

Chen, D., Liu, Z., Wang, L., Dou, M., Chen, J., \& Li, H. (2013). Natural Disaster Monitoring with Wireless Sensor Networks: A Case Study of Data-Intensive Applications upon Low-Cost Scalable Systems. Mobile Networks and Applications, 18(5), 651-663.

Chen, X., \& Vierling, L. (2006). Spectral Mixture Analyses of Hyperspectral Data Acquired using a Tethered Balloon. Remote Sensing of Environment, 103(3), 338-350.

Clapuyt, F., Vanacker, V., \& Van Oost, K. (2016). Reproducibility of UAV-Based Earth Topography Reconstructions Based on Structure-from-Motion Algorithms. Geomorphology, 260, 4-15.

Clark, A. (2017). Small Unmanned Aerial Systems Comparative Analysis for the Application to Coastal Erosion Monitoring. GeoResJ, 13, 175-185.

Colomina, I., \& Molina, P. (2014). Unmanned Aerial Systems for Photogrammetry and Remote Sensing: A Review. ISPRS Journal of Photogrammetry and Remote Sensing, 92, 79-97.

Conniff, R., \& McClaran, R. (2011, June). Drones are Ready for Takeoff. Smithsonian Magazine, 41-54.

Cook, K. L. (2017). An Evaluation of the Effectiveness of LowCost UAVs and Structure from Motion for Geomorphic Change Detection. Geomorphology, 278, 195-208.

Coppa, U., Guarnieri, A., Pirotti, F., \& Vettore, A. (2009). Accuracy Enhancement of Unmanned Helicopter Positioning with Low-Cost System. Applied Geomatics, 1(3), 85-95.
Delacourt, C., Allemand, P., Grandjean, P., Deschamps, A., Ammann, J., Cuq, V., \& Suanez, S. (2009). DRELIO: An Unmanned Helicopter for Imaging Coastal Areas. Journal of Coastal Research, 56, 1489-1493.

Dubbini, M., Curzio, L. I., \& Campedelli, A. (2016). Digital Elevation Models from Unmanned Aerial Vehicle Surveys for Archaeological Interpretation of Terrain Anomalies: Case study of the Roman Castrum of Burnum (Croatia). Journal of Archaeological Science: Reports, 8, 121-134.

Eisenbeiss, H. (2004). A Mini Unmanned Aerial Vehicle (UAV): System Overview and Image Acquisition. Proceedings of the International Workshop on Processing and Visualization Using High-Resolution Imagery, 1-7.

Elias, Z., Hamin, Z., \& Othman, M. B. (2013). Sustainable Management of Flood Risks in Malaysia: Some Lessons from the Legislation in England and Wales. Procedia - Social and Behavioral Sciences, 105, 491-497.

Erdelj, M., Król, M., \& Natalizio, E. (2017). Wireless Sensor Networks and Multi-UAV Systems for Natural Disaster Management. Computer Networks, 124, 72-86.

Fan, Y. M., Ding, M., \& Cao, Y. F. (2017). Vision Algorithms for Fixed-Wing Unmanned Aerial Vehicle Landing System. Science China Technological Sciences, 60(3), 434-443.

Feng, Q., Liu, J., \& Gong, J. (2015). Urban Flood Mapping Based on Unmanned Aerial Vehicle Remote Sensing and Random Forest Classifier: A Case of Yuyao, China. Water, 7(4), 14371455.

Flynn, K. F., \& Chapra, S. C. (2014). Remote Sensing of Submerged Aquatic Vegetation in a Shallow Non-Turbid River using an Unmanned Aerial Vehicle. Remote Sensing, 6(12), $12815-12836$.

Fonstad, M. A., Dietrich, J. T., Courville, B. C., Jensen, J. L., \& Carbonneau, P. E. (2013). Topographic Structure From Motion: A New Development in Photogrammetric Measurement. Earth Surface Processes and Landforms, 38(4), 421-430.

Gerke, M., Masár, I., Borgolte, U., \& Röhrig, C. (2013). Farmland Monitoring by Sensor Networks and Airships. IFAC Conference on Modelling and Control in Agriculture, Holticulture and Post Harvest Industry, 4, 321-326.

Gomez, C., \& Purdie, H. (2016). UAV-Based Photogrammetry and Geocomputing for Hazards and Disaster Risk Monitoring A Review. Geoenvironmental Disasters, 3(1), 23.

Gstaiger, V., Huth, J., Gebhardt, S., Wehrmann, T., \& Kuenzer, C. (2012). Multi-Sensoral and Automated Derivation of Inundated Areas using TerraSAR-X and ENVISAT ASAR Data. International Journal of Remote Sensing, 33(22), 7291-7304.

Hamin, Z., Othman, M. B., \& Elias, Z. (2013). Floating on a Legislative Framework in Flood Management in Malaysia: Lessons from the United Kingdom. Procedia - Social and Behavioral Sciences, 101, 277-283.

Hong, S., Jeong, J., Kim, S., Suk, J., \& Jung, J. I. (2013). Longitudinal Flight Dynamics of a Single Tilt-Wing Unmanned 
Aerial Vehicle. 19th IFAC Proceedings Volumes, 46(5), 60-65.

Kadir, H. A., \& Arshad, M. R. (2015). Cooperative Multi Agent System for Ocean Observation System based on Consensus Algorithm. Procedia Computer Science, 76, 203-208.

Kia, M. B., Pirasteh, S., Pradhan, B., Mahmud, A. R., Sulaiman, W. N. A., \& Moradi, A. (2012). An Artificial Neural Network Model for Flood Simulation using GIS: Johor River Basin, Malaysia. Environmental Earth Sciences, 67(1), 251-264.

Klemas, V. (2013). Airborne Remote Sensing of Coastal Features and Processes: An Overview. Journal of Coastal Research, 29(2), 239-255.

Klemas, V. (2015). Coastal and Environmental Remote Sensing from Unmanned Aerial Vehicles: An Overview. Journal of Coastal Research, 31(5), 1260-1267.

Kourgialas, N. N., \& Karatzas, G. P. (2017). A National Scale Flood Hazard Mapping Methodology: The case of Greece Protection and Adaptation Policy Approaches. Science of the Total Environment, 601-602, 441-452.

Lacroix, S., Jung, I. K., \& Mallet, A. (2002). Digital Elevation Map Building from Low Altitude Stereo Imagery. Robotics and Autonomous Systems, 41(2-3), 119-127.

Mancini, F., Dubbini, M., Gattelli, M., Stecchi, F., Fabbri, S., \& Gabbianelli, G. (2013). Using Unmanned Aerial Vehicles (UAV) for High-Resolution Reconstruction of Topography: The Structure from Motion Approach on Coastal Environments. Remote Sensing, 5(12), 6880-6898.

McMindes, K. L. (2005). Unmanned Aerial Vehicle Survivability: the Impacts of Speed, Detectability, Altitude, and Enemy Capabilities. Calhoun, Monterey, California.

Milstein, M. (2011). Unmanned Aerial Vehicles Redefine the Term Non Stop Flight.

Mohammed, T. A., Al-Hassoun, S., \& Ghazali, A. H. (2011). Prediction of Flood Levels along a Stretch of the Langat River with Insufficient Hydrological Data. Pertanika Journal of Science and Technology, 19(2), 237-248.

Mohd, T., Saraf, M. H. M., Pin, S. F. B. C., \& Hasbullah, M. N. (2016). Designing the Invention House Assessment Form for Kuala Krai, Malaysia. Procedia - Social and Behavioral Sciences, 234, 317-325.

Mohit, M. A., \& Sellu, G. M. (2013). Mitigation of Climate Change Effects through Non-Structural Flood Disaster Management in Pekan Town, Malaysia. Procedia - Social and Behavioral Sciences, 85, 564-573.

Mozas-Calvache, A. T., Pérez-García, J. L., Cardenal-Escarcena, F. J., Mata-Castro, E., \& Delgado-García, J. (2012). Method for Photogrammetric Surveying of Archaeological Sites with Light Aerial Platforms. Journal of Archaeological Science, 39(2), 521530 .

Muhamad, N., Lim, C. S., Reza, M. I. H., \& Pereira, J. J. (2015). Urban Hazards Management: A Case Study of Langat River Basin, Peninsular Malaysia. International Conference on Space
Science and Communication, 438-443.

Mustaffa, C. S., Marzuki, N. A., Ariffin, M. T., Salleh, N. 'Aaina, \& Rahaman, N. H. (2014). Relationship between Social Support, Impression Management and Well-Being among Flood Victims in Malaysia. Procedia - Social and Behavioral Sciences, 155, 197-202.

Nagai, M., Shibasaki, R., Manandhar, D., \& Zhao, H. (2004). Development of Digital Surface Model and Feature Extraction By Integrating Laser Scanner and CCD Sensor With IMU. The International Archives of the Photogrammetry, Remote Sensing and Spatial Information Sciences, XXXV(B5), 781-785.

Nitta, Y., Inai, S., Matsumura, K., Ishida, M., Onai, T., \& Nishitani, A. (2017). The Visual Inspection Methodology for Ceiling Utilizing the Blimp. Procedia Engineering, 188, 256262.

OCHA. (2017). Asia and the Pacific: Weekly Regional Humanitarian Snapshot.

Othman, A. Z., Dahlan, A., Borhani, S. N., \& Rusdi, H. (2016). Post-Traumatic Stress Disorder and Quality of Life among Flood Disaster Victims. Procedia - Social and Behavioral Sciences, $234,125-134$.

Perks, M. T., Russell, A. J., \& Large, A. R. G. (2016). Technical Note: Advances in Flash Flood Monitoring Using Unmanned Aerial Vehicles (UAVs). Hydrology and Earth System Sciences, 20(10), 4005-4015.

Polo, J., Hornero, G., Duijneveld, C., García, A., \& Casas, O. (2015). Design of a Low-Cost Wireless Sensor Network with UAV Mobile Node for Agricultural Applications. Computers and Electronics in Agriculture, 119, 19-32.

Pregnolato, M., Ford, A., Wilkinson, S. M., \& Dawson, R. J. (2017). The Impact of Flooding on Road Transport: A DepthDisruption Function. Transportation Research Part D: Transport and Environment, 55, 67-81.

Ruiz Estrada, M. A., Koutronas, E., Tahir, M., \& Mansor, N. (2017). Hydrological Hazard assessment: The 2014-15 Malaysia Floods. International Journal of Disaster Risk Reduction, 24(June), 264-270.

Salleh, S. H. M., \& Sidek, L. M. (2016). Enhancing a Distributed Rainfall Intensity for Flood Analysis within a GIS Framework in an Urban Area (Kajang Flood). IOP Conference Series: Earth and Environmental Science, 32(1), 20-24.

Shen, D., Rui, Y., Wang, J., Zhang, Y., \& Cheng, L. (2015). Flood Inundation Extent Mapping based on Block Compressed Tracing. Computers and Geosciences, 80, 74-83.

Sik, H., Chool, J., Sik, M., Joon, I., \& Kyum, C. (2004). Construction of National Cultural Heritage Management System. ISPRS Archives, $X X X V(\mathrm{~B} 5), 473-478$.

Sipon, S., Sakdan, M. F., Mustaffa, C. S., Marzuki, N. A., Khalid, M. S., Ariffin, M. T., ... Abdullah, S. (2015). Spirituality among Flood Victims: A Comparison between Two States. Procedia Social and Behavioral Sciences, 185, 357-360. 
Sunkpho, J., \& Ootamakorn, C. (2011). Real-Time Flood Monitoring and Warning System. Songklanakarin Journal of Science and Technology, 33(2), 227-235.

Tahar, K., \& Ahmad, A. (2012). A Simulation Study on the Capabilities of Rotor Wing Unmanned Aerial Vehicle in Aerial Terrain Mapping. International Journal of the Physical Sciences, 7(8), 1300-1306.

Tamás Fráter, Tatjána Juzsakova, János Lauer, László Dióssy, \& Ákos Rédey. (2015). Unmanned Aerial Vehicles in Environmental Monitoring-An Efficient Way for Remote Sensing. Journal of Environmental Science and Engineering, 4(2), 85-91.

Tatham, P., Stadler, F., Murray, A., \& Shaban, R. Z. (2017). Flying Maggots: A Smart Logistic Solution to An Enduring Medical Challenge. Journal of Humanitarian Logistics and Supply Chain Management, 7(2), 172-193.

Tuna, G., Mumcu, T. V., Gulez, K., Gungor, V. C., \& Erturk, H. (2012). Unmanned Aerial Vehicle Aided Wireless Sensor Network Deployment System for Post-Disaster Monitoring. Communications in Computer and Information Science, 304, 298-305.

Uysal, M., Toprak, A. S., \& Polat, N. (2015). DEM Generation with UAV Photogrammetry and Accuracy Analysis in Sahitler hill. Measurement: Journal of the International Measurement Confederation, 73, 539-543.

Verhoeven, G. J. J. (2009). Providing an Archaeological Bird'sEye View - An overall Picture of Ground-Based Means to Execute Low-Altitude Aerial Photography (LAAP) in Archaeology. Archaeological Prospection, 16(4), 233-249.

Verhoeven, G. J. J., Loenders, J., Vermeulen, F., \& Docter, R. (2009). Helikite Aerial Photography - A Aersatile Means of Unmanned, Radio Controlled, Low-Altitude Aerial Archaeology. Archaeological Prospection, 16(2), 125-138.

Verhoeven, G., Taelman, D., \& Vermeulen, F. (2012). Computer Vision-Based Orthophoto Mapping Of Complex Archaeological Sites: The Ancient Quarry Of Pitaranha (Portugal-Spain). Archaeometry, 54(6), 1114-1129.

Vericat, D., Brasington, J., Wheaton, J., \& Cowie, M. (2008). Accuracy Assessment of Aerial Photographs Acquired Using Lighter Than Air Blimps: Low Cost Tools for Mapping River Corridors. River Research and Applications, 25(8), 985-1000.

Wardah, T., Abu Bakar, S. H., Bardossy, A., \& Maznorizan, M. (2008). Use of Geostationary Meteorological Satellite Images in Convective Rain Estimation for Flash-Flood Forecasting. Journal of Hydrology, 356, 283-298.

Watanabe, Y., \& Kawahara, Y. (2016). UAV Photogrammetry for Monitoring Changes in River Topography and Vegetation. Procedia Engineering, 154, 317-325.

Woodget, A. S., Austrums, R., Maddock, I. P., \& Habit, E. (2017). Drones and Digital Photogrammetry: From Classifications to Continuums for Monitoring River Habitat and Hydromorphology. Wiley Interdisciplinary Reviews: Water, 4(4), 1-20.
Xiao, Y., Yi, S., \& Tang, Z. (2017). Integrated Flood Hazard Assessment based on Spatial Ordered Weighted Averaging Method Considering Spatial Heterogeneity of Risk Preference. Science of the Total Environment, 599-600, 1034-1046.

Zhang, D., Quan, J., Zhang, H., Wang, F., Wang, H., \& He, X. (2015). Flash Flood Hazard Mapping: A Pilot Case Study in Xiapu River Basin, China. Water Science and Engineering, 8(3), 195-204.

Zoccatelli, D., Borga, M., Zanon, F., Antonescu, B., \& Stancalie, G. (2010). Which Rainfall Spatial Information for Flash Flood Response Modelling? A Numerical Investigation Based on Data from the Carpathian Range, Romania. Journal of Hydrology, 394, 148-161. 